\title{
Quality Improvement of the Teaching Practice Component of the PGDE Programme
}

\author{
G.D. Lekamge ${ }^{1}$ \\ gdlek@ou.ac.lk
}

The Faculty of Education prepared an action plan with the aim of improving the quality of different aspects of teaching practice of a professional training programme offered by the Open University of Sri Lanka. The target group consisted of Lecturers, Master Teachers, School Mentors and student teachers who had been involved in the teaching practice component of the programme for sometime. A variety of methods were used for collecting data which were analyzed and interpreted at different stages of the project. Certain critical problems and issues were identified and suitable strategies to overcome the problems were explored. Further, the experience gained by implementing some of the best strategies was analyzed and possible changes that should be made to improve them further were discussed. It was envisaged that the whole activity would make a strong impact on the professional development of student teachers thereby improving the quality of the programme conducted by the Faculty

\section{The context}

The quality of teaching depends on the quality of teachers in the system. There is research evidence to believe that teacher education has a positive impact on teachers' perceptions of their own teaching competencies. The adoption of the distance education mode for the teacher education programmes has also been recognized as a solution to many problems in the teacher training programmes in developing countries. However, distance education programmes are questionable because of their ineffectiveness in transferring the required skills and attributes to student teachers. Further, it is believed that the teachers engaged in part-time or distance-mode studies do not spend sufficient time to make maximum use of the opportunity given to them because they are engaged in full-time work and/or other responsibilities. Some writers maintain that teacher education has relatively little impact on classroom practice (Stuart \& Thurlow, 2000) and some arguably attribute ineffectiveness of teacher education to the type and design of teacher training being provided (Kennedy, 1999). 
Therefore, the distance education mode while catering to larger numbers, also attempts to improve the quality of training provided for teachers. One mechanism recognized by teacher education institutes for professional development of student teachers is 'mentoring' even though there is little consensus in the literature on what mentoring is. It is important to note that a large number of discussions on mentoring are related to initial teacher education and only very little has been done on in-service teacher education. Some writers focus on the relational dimension of mentoring especially on the relationship between the mentor and mentee. Several others focus on the development dimension of mentoring i.e. on professional development of both mentors and mentees. Maynard and Furlong (1993) developed three models of mentoring which correspond to the changing needs of teacher trainees in practice situations. In the light of the research literature, there was a need to revisit the teacher education programmes conduced by the Open University of Sri Lanka to incorporate some of the new strategies identified through example and practice.

The Open University of Sri Lanka (OUSL) has been conducting teacher education programmes since its inception. The PGDE programme which is the largest and oldest programme of the OUSL has been focusing on improving professional competencies of in-service teachers. The student teachers enrolled in the programme are supported by quality modules, a limited number of day schools and tutorials. The programme has a strong focus on the teaching practice component as a means of developing the teaching skills of the teachers. Nearly 400 Master Teachers and 75 university academics support the university in monitoring, supervising and evaluating the teaching practice of these student teachers.

While catering to the increasing demands arising from teachers in the school system, the Faculty of Education has introduced some minor and major changes to improve the quality of the PGDE programme. A small scale survey conducted by the Faculty had revealed a number of limitations in the procedures implemented for Teaching Practice which may directly have an impact not only on the quality of the programme but also on the quality of the teachers produced. Therefore, several innovative strategies have been introduced at different stages on an experimental basis to achieve the overall aim of improving the quality of the teaching practice (TP) component of the PGDE programmes. This paper critically analyses the experience gained by the research team in designing, implementing and monitoring new strategies and also 
assessing the effectiveness of those strategies to achieve the intended outcomes.

\section{Objectives}

Four objectives were identified in line with this research project as follows:

1. To analyze the problems faced by student teachers, Master Teachers and the Faculty staff in implementing the teaching practice component and the reasons leading to such problems

2. To examine the relevance of selected innovative strategies to overcome the problems analyzed and to improve the quality of the teaching practice component

3. To analyze the experience gained by implementing new strategies and to evaluate the effectiveness of those strategies to achieve intended outcomes

4. To make recommendations for further improvement of the quality of the teaching practice component

\section{Methodology}

Target group and sample

The academic staff of the Faculty of Education who are involved in Teaching Practice Stage II , Master Teachers, School Mentors and students following the PGDE Programme were identified as the target group of this study.

Internal academics (15) Lecturers of the Colleges of Education (8), Master Teachers (30) of the Teaching Practice Stage I and a selected set of Principals (30), student teachers (30) and School Mentors (30) were invited and used at different stages of the project for data collection and it was believed that all the above categories would benefit in different ways after completing this project.

Methods used for Data Collection

Three brainstorming sessions were conducted with internal academics of the Faculties of Education, OUSL (15) and University of Colombo 
(01) and lecturers of NCOE (8) to identify the main issues and concerns of the Faculty with regard to the teaching practice component and to develop a plan to improve the quality of the TP component. The discussions and brainstorming sessions were further enhanced by the information collected during the informal discussions with the student teachers and Master Teachers and by conducting Teaching Practice Stage II sessions.

In addition, three workshops were held to provide opportunities for self reflection on the experience gained, group discussions and participatory observations for different categories of people involved in Teaching Practice. At the end of each focus group discussion, group leaders with the support of rapporteuers made presentations to the rest of the groups and lengthy discussions took place to finalize the main considerations. Only those who had participated in the brainstorming sessions were called for these workshops.

The evaluation forms submitted by School Mentors (30) at the end of Teaching Practice Stage 1 on the progress of student teachers, their reflective journals, the information collected at the monitoring workshops held with Master Teachers and student teachers and the reports on the observations of Faculty staff (15) during organized school visits supported the evaluation mechanism and helped to arrive at final action.

Qualitative analysis techniques were used to maintain the originality of data collected through a variety of techniques mentioned above.

\section{Problems faced by those engaged in the conduct of Teaching Practice}

The crucial problems revealed through the analysis of focus group discussions, the discussions at monitoring workshops and the reports produced on organizational visits to schools could be grouped under three areas which were related to the three categories of people involved in the Teaching Practice component.

\subsection{Problems experienced by Master Teachers:}

The problems faced by Master Teachers relate mainly to the appointment of incompetent personnel as Master Teachers which had resulted in rapid deterioration of professional standards. Other problems include inadequately formulated training programmes with 
limited focus conducted by the Faculty, the increasing number of students being allocated to each Master Teachers for evaluation of Teaching Practice, the lack of commitment on the part of student teachers to improve professional skills and the difficulties faced by Master Teachers as a result of certain student teachers working in rural schools being allocated to them. It was also revealed that some Master Teachers were confused about their roles as some concentrated mainly on the assessment role rather than the guidance and supervisory roles. The lack of a proper mechanism to monitor their activities and give necessary feedback on time was also identified as a problem connected with some newly appointed Master Teachers. In addition, getting approval from relevant authorities for duty leave for supervision of teaching practice also emerged as a major issue. Lack of understanding and communication between the Faculty and employers of Master Teachers was identified as a reason for such problems. .

\subsection{Problems experienced by student teachers:}

Student teachers, pointed out that they have limited opportunities to interact with their Master Teachers and Faculty staff during the Teaching Practice period and that they received limited support from the principals and fellow teachers in their schools. They also experienced difficulties in applying theory into practice and showed little interest in using innovative teaching aids and methods to teach their students due to limited facilities available in the schools. Some lecturers were of the opinion that student teachers were only interested in collecting their certificates rather than upgrading their professional skills. Concerns were also raised by the student teachers about the discrepancies that existed between supervision and guidance by Master Teachers, lack of support from the Faculty and their own personal difficulties that they faced during the Teaching Practice period . They also complained about delays in commencing TP by Master Teachers, difficulties in changing school time tables to suit the needs of teachers during TP, the appointments given to rural schools and transfers received during Teaching Practice period which was a drawback for the completion of Teaching Practice in the time allocated .

\subsection{Problems experienced by Faculty and Staff}

The selection of competent Master Teachers and allocation of student teachers to Master Teachers were identified as some of the crucial issues faced by the Faculty. Other concerns were the lack of experience 
and training of Faculty staff to perform their roles in an effective manner as university academics, lack of commitment and lack of interest on the part of Master Teachers to provide continuous guidance and support to student teachers. In addition, leave taken by both student teachers and Master Teachers during the Teaching Practice period, delays in completing Teaching Practice supervision by Master Teachers and delays in making payments for Master Teachers were the other problems highlighted by them which directly affected the satisfactory completion of the teaching practice component. The problems that arose because of the limited interaction between the Faculty Staff and schools and Faculty staff and student teachers during the early stages of Teaching Practice were also noted. A strong emphasis was placed by the Faculty staff on the unforeseen problems beyond their control which would affect the smooth functioning of Teaching Practice. The Faculty also faces problems when marks and relevant documents are delayed by lecturers and Master Teachers and also when university academics are released to complete Teaching Practice Stage II for a long periods depending on the number of students involved. When large numbers of student teachers are enrolled in the programme internal academics have to be fully involved in Teaching Practice Stage II for a long periods.This adversely affects the effective execution of their duties at the Department and Faculty level.

\section{Appropriate strategies to overcome the problems identified}

The research project looked at appropriate strategies to overcome problems faced by the three categories of persons involved in Teaching Practice. The identification of strategies were based on the information collected at brainstorming sessions, workshops and focus group discussions and the reports produced on monitoring workshops by the internal academics.

\subsection{Appropriate Strategies identified to solve Master Teachers' problems}

Having triangulated the information gathered from different sources such as focus group discussions, group presentations and documents produced by Master Teachers, Lecturers and School Mentors the following were identified as the most effective strategies to solve the problems and issues faced by Master Teachers. One of the most prominent strategies was to extend the training programme conducted 
for Master Teachers to at least to two days and to concentrate on the attitudinal changes and development of personal characteristics of Master Teachers. Another procedure identified was to introduce short courses aimed at updating knowledge and skills of Master Teachers by the Faculty and request every Master Teacher to follow these courses in order to qualify to continue their work as Master Teachers.

Lecturers pointed out that two cycles could be conducted for Teaching Practice Stage I \& II to solve the problems related to the lack of quality Master Teachers. However, when allocating student teachers for the second cycle, the availability of Master Teachers would be checked. In order to reduce the communication and commuting difficulties faced by Master Teachers, they should be allowed to bring student teachers to a schools situated in close proximity to the schools in which Mater teachers are employed in order to complete Teaching Practice Stage I under special circumstances.

A strong need was identified for re-defining the roles and responsibilities of Master Teachers and the suggestions arrived at could be summarized into four main roles :

(a) Supervision- Strictly adhere to the procedure adopted by the University.

(b) Development of skills - A collaborative approach should be implemented with student teachers.

(c) Assessment- Continuous evaluation, monitoring and providing feedback to student teachers

(d) Reporting- Recording the progress and sending reports to the University on time.

There were concerns raised on the need to emphasize the supportive role of Master Teachers rather than an evaluative role and to ascertain a suitable mechanism to ensure the fulfillment of Master Teachers' responsibilities. . One such mechanism was to revise strategies implemented by the Master Teachers to conduct the initial meeting with student teachers. At this meeting, Master Teachers could focus on the development of an action plan for completion of TP I along with the student teachers, giving common advice and individual advice on the lesson plans written by student teachers (student teachers should be asked to bring the lesson notes completed and write reflective notes on the advice given), the need for applying new methodologies and 
innovative teaching aids and having a discussion to improve the student teachers' commitment towards teaching. The rest of the time (at least one hour) should be spent on the following: the schedule for supervising TP, problems of student teachers and their solutions, identification of lessons, time slots and classrooms, leave etc.

\subsection{Appropriate strategies to solve problems experienced by Student Teachers}

One good strategy suggested by many lecturers and Master Teachers was the identification of specific competencies that should be developed in student teachers. The disparities that exist among competencies of Master Teachers may have aggravated the problems. It was further anticipated that a clear demarcation of competencies should be incorporated into the guidelines of both Master Teachers and student teachers. The following were agreed upon in the discussions though they were not totally new to both Lecturers and Master Teachers. What is significant is that this process led to a consensus among different categories of personnel about the competencies of student teachers.

- Ability to plan and conduct lessons of good quality

- $\quad$ Ability to produce and use effective teaching aids with different levels of students

- Ability to use methods and strategies which would facilitate the development of higher order cognitive skills in students

- Ability to use appropriate assessment strategies throughout the lesson

- $\quad$ Ability to cater to the needs of Special Needs Children

- $\quad$ Ability to reflect on their experiences as a way of improving quality of their practice

- $\quad$ Ability to manage students and resources effectively and efficiently

- $\quad$ Ability to prepare and use innovative teaching-learning aids

- $\quad$ Ability to maintain a friendly relationship with other teachers 
and students

- $\quad$ Ability to demonstrate a positive attitude and a strong commitment towards teaching

The second innovative strategy identified in the discussions was the appointment of a School Mentor and conducting intensive training programmes in order for them to be familiar with the expected roles and responsibilities. The responsibilities of School Mentors were specified under five main categories:

- To develop positive attitudes towards teaching and other school activities

- To provide continuous guidance and support to student teachers to fulfill their duties and responsibilities effectively

- To assure better facilities for teaching-learning within the school

- To supervise a project at school level that would contribute to the development of professional skills of student teachers and infrastructure of the school

- To liaise with the school principal, Master Teacher and student teachers

In order to improve the school participation and to provide a close supervision to student teachers, a qualified and experienced teacher should be identified from the school to work as the School Mentor. There was also a need to derive a common definition about the School Mentor. At the same time, a mechanism should be in place to increase the awareness of the principals about their responsibilities in facilitating the development of professional competencies of student teachers. A mechanism to increase the involvement of student teachers in developing their schools (co-curricular activities) should also be implemented, monitored and supervised. It was further recommended that this also should be a part of the internal monitoring process of the school.

It was further suggested that a project to increase the student teachers' involvement in day-to-day activities of their schools be introduced. This was to be a short-term project of five to seven days duration which 
would focus on improving extra-curricular activities and the infrastructure of the school. Student teachers were to implement the project under the close monitoring of School Mentors and school principals.

\subsection{Appropriate strategies to overcome the problems experienced by the Faculty Staff :}

It was pointed out that each university staff member should be given the responsibility for monitoring the activities of a group of Master Teachers and the student teachers allocated to them. This procedure would strengthen the interaction between the Faculty and Master Teachers and also avoid delays in conducting Teaching Practice Stage I. Having allocated Master Teachers to University academics the following procedures could be implemented to benefit all parties concerned:

1. A workshop should be conducted after 5 weeks with Master Teachers and student teachers to monitor the progress of Teaching Practice Stage I. At the workshop student teachers should submit a report about the usefulness of the supervision provided by the Master Teachers. A discussion should be held with both Master Teachers and student teachers to rectify problems faced by them. In this way, immediate feedback can be given to respective student teachers as well as Master Teachers.

2. It is of utmost importance that Faculty staff should do random visits to schools. The purpose of these visits would be to get firsthand experience about teaching abilities of student teachers and the supervisory role practiced by the Master Teachers.

3. A mechanism should be implemented by the Faculty to increase the awareness of school principals about the importance of developing professional skills of student teachers.

4. Several evaluation and feedback mechanisms should be developed and data be collected and analyzed to identify the effectiveness of the newly introduced procedures.

5. At the commencement and conclusion of Teaching Practice, University academics should share their experiences and review the procedures applied through presentations at workshops. 
6. Analysis of the experience gained by implementing new strategies

Having identified the strategies to be implemented to improve the Teaching Practice component, they were implemented on an experimental basis for the batch of student enrolled for the academic year 2009/2010. The Faculty was very concerned about the strengths and weaknesses of the innovative strategies introduced and their contributions for the achievement of the final outcomes of the programme. Therefore, self reflections of student teachers and Mentors in their reflective journals and evaluation reports produced by university academics, Master Teachers and School Mentors were analyzed and interpreted in order to get an insight into practical situations. In the following section, the outcomes of three main strategies implemented in the project for the attainment of the main objectives of the project are considered.

\section{How effective is School Mentoring?}

Overall, mentoring was a very positive experience for all the categories of people involved in Teaching Practice of the PGDE Programme. In this process, qualified and experienced teachers have been identified from the same schools where the student teachers were teaching and appointed as School Mentors in addition to Master Teachers who have been involved in supervising Teaching Practice of student teachers throughout the ten week period. Initially the plan was to introduce this new system to the schools in the Western Province only. However, later it was introduced to all the provinces with the support of the University. However, the data analyzed here is confined to the Western Province only ( 30 School Mentors) .

A considerable number of School Mentors (64\%) revealed that they were very enthusiastic about their new role which was very 'rewarding' and the training workshops conducted by the Faculty had supported them to be fully equipped with the necessary knowledge, skills and attitudes. There were systematic procedures in place by the Faculty through School Mentors to assess the capabilities of student teachers at the commencement of the teaching period and to monitor the progress throughout the ten weeks period. Some School Mentors (70\%) admitted that they themselves had benefited by taking part in the well planned and appropriately focused professional development activities. 
Through this process they were able to gain an insight into new knowledge and skills, improve managerial and leadership capacities, strengthen their self regulatory practices and inculcate a positive attitude among their school colleagues about themselves. At the same time, they had become self critical and reflective in their own practices. Some positive and negative comments given by student teachers are listed in the Table 1.

Table 1. Comments made by student teachers about School Mentors

\begin{tabular}{|l|l|}
\hline \multicolumn{1}{|c|}{ Positive Comments } & \multicolumn{1}{c|}{ Negative comments } \\
\hline $\begin{array}{l}\text { My mentor is very friendly and } \\
\text { supportive }\end{array}$ & Mentor was very busy \\
\hline I am looked after well by my mentor & $\begin{array}{l}\text { Mentor was unaware about reflective } \\
\text { writing }\end{array}$ \\
\hline Mentor is very knowledgeable & $\begin{array}{l}\text { Mentor was not very clear about the } \\
\text { project }\end{array}$ \\
\hline $\begin{array}{l}\text { I was able to achieve a substantial } \\
\text { progress under mentor's guidance }\end{array}$ & $\begin{array}{l}\text { No opportunities for a mutual } \\
\text { understanding }\end{array}$ \\
\hline I received feedback on the spot & \begin{tabular}{l} 
My mentor takes all the decisions \\
\hline
\end{tabular}
\end{tabular}

There was a strong belief that the effectiveness of mentoring was directly related to the mutual understanding and professional relationship developed between student teachers and School Mentors. The students regarded the personal attributes of School Mentors as a key to the success of mentoring and expressed their satisfaction about the immediate feedback and friendly support received from their School Mentors. Student teachers were very positive about the support received from School Mentors to liaise with the school principals and to develop a facilitative culture within the school. The psychological support and instruction -related support received from mentors help student teachers to gain independence as professionals who are empowered to draw from a foundation of experience based knowledge and skills. The evaluation forms produced by school mentors at the beginning of Teaching Practice and at the end of Teaching Practice have given indications about the strengths and the weaknesses of each 
student teacher and the involvement of School Mentors to improve their professional skills throughout the period.

During school visits of internal academics, it was reported that more than half the principals (57\%) admitted that the appointment of School Mentors is a very positive move and this procedure would definitely lead to a qualitative change in all aspects involved. However, it was evident that School Mentors carried out their mentoring role in addition to their regular duties associated with their posts in schools. Therefore, both student teachers and School Mentors were concerned about not being able to spend sufficient time together to strengthen the professional skills of student teachers. In some schools, appointment of experienced and qualified staff to work as School Mentors was a problem due to lack of qualified staff. It was revealed that some mentors had difficulties in complying with the instructions issued by the Faculty due to various difficulties arising from the school environment.

\section{What are the outcomes of school projects?}

For the first time its history, a school based project was introduced to the PGDE Programme by the Faculty. This was a novel experience for the University academics as well as the School Mentors and Master Teachers though many overwhelmingly accepted it as a very worthwhile and meaningful strategy. The principals (70\%) were of the opinion that school projects positively contributed to the development of infrastructure and co-curricular activities of the schools. As reported in the student teachers' and School Mentors' reflective journals this mechanism has provided a very good platform to experiment various innovative ideas. Among the projects completed by student teachers, there were 'value trees', herbal gardens, landscaping projects, class libraries, exhibitions, debating campaigns, wall magazines, nutrition programmes, literacy programmes, quiz competitions, musical programmes, wall paintings, science and mathematics days and many more. Some mentors (44\%) have managed to convince the school principals to facilitate this process by providing financial assistance through quality inputs of their schools. A considerable number of student teachers also expressed the view that the project was a worthwhile experience for them. They have mentioned about the personal benefits ads well as benefits Comments made by student teachers about the projects are listed in the Table 2. 
Quality Improvement of the Teaching Practice Component of the PGDE Programme

Table 2- Comments made by student teachers about the projects

\begin{tabular}{|l|l|}
\hline \multicolumn{1}{|c|}{ Positive comments } & \multicolumn{1}{c|}{ Negative comments } \\
\hline $\begin{array}{l}\text { I have gained a lot by completing the } \\
\text { project }\end{array}$ & $\begin{array}{l}\text { I am not very clear about writing } \\
\text { objectives }\end{array}$ \\
\hline $\begin{array}{l}\text { My recognition has been improved due } \\
\text { to completion of the project }\end{array}$ & $\begin{array}{l}\text { More guidance is needed for reflective } \\
\text { writing }\end{array}$ \\
\hline $\begin{array}{l}\text { I was very happy to see my project } \\
\text { moving well }\end{array}$ & $\begin{array}{l}\text { I am unable to complete the project as } \\
\text { I have to complete more lessons }\end{array}$ \\
\hline $\begin{array}{l}\text { I experience a positive change in my } \\
\text { attitudes through the completion of the } \\
\text { project }\end{array}$ & $\begin{array}{l}\text { Teaching Practice period is not the } \\
\text { correct time to complete a project }\end{array}$ \\
\hline $\begin{array}{l}\text { I was able to increase the involvement } \\
\text { of students in co-curricular activities } \\
\text { through the project }\end{array}$ & $\begin{array}{l}\text { I am left alone without any guidance } \\
\text { for the project }\end{array}$ \\
\hline
\end{tabular}

However, there was evidence that both student teachers and School Mentors had difficulties in preparing reflective journals about the completed activities of the projects. According to some student teachers they were over burdened with numerous responsibilities in the school during Teaching Practice period and the project further magnified their problems. School Mentors (38\%) had problems with lack of interest, initiation and commitment of student teachers. Some student teachers and School Mentors pointed out that limited facilities available in the schools acted as a barrier for selection of innovative and novel projects. Further, there were numerous difficulties faced by both student teachers and School Mentors due to unforeseen problems in the schools.

\section{How successful is the monitoring mechanism implemented by University Academics?}

There was a felt need to introduce a mechanism to monitor activities of both Master Teachers and student teachers during Teaching Practice period. Therefore, all the Master Teachers were assigned to University academics and they were asked to conduct a workshop for monitoring activities of Master Teachers. At the workshop, the progress of the teaching practice component was monitored, problems of student 
teachers and Master Teachers were analyzed and possible solutions were discussed. From the University point of view this workshop was very helpful for reviewing the progress of writing lesson notes, completion of lessons, preparation of teaching aids, developing the research proposals and directing all available facilities to complete the project. In addition, the work of the Maser Teachers could be monitored and anomalies could be rectified. This workshop had provided opportunities for both Master Teachers and student teachers to share their concerns in the presence of the University academics. Some of the comments made by University academics and Master Teachers are listed below. According to these comments, some Master Teachers were not very happy with the arrangements made by the Faculty for conducting a monitoring workshop. However, from the Faculty's point of view, this procedure contributed immensely to achieve the expected outcomes and almost all the academics recommended it to be continued every year after five weeks of Teaching Practice. However, some Master Teachers were not very happy about the monitoring workshop.

Table 3- Comments about the monitoring workshop

\begin{tabular}{|l|l|}
\hline \multicolumn{1}{|c|}{$\begin{array}{c}\text { About the workshop (University } \\
\text { academics) }\end{array}$} & \multicolumn{1}{c|}{$\begin{array}{c}\text { About the workshop( Master } \\
\text { Teachers) }\end{array}$} \\
\hline $\begin{array}{l}\text { Workshop was very useful to assess } \\
\text { the progress of Master Teachers }\end{array}$ & $\begin{array}{l}\text { Workshop should be arranged at an } \\
\text { early stage to get the maximum benefit } \\
\text { for everybody }\end{array}$ \\
\hline $\begin{array}{l}\text { Provided a very good opportunity to } \\
\text { solve problems on the spot }\end{array}$ & $\begin{array}{l}\text { Objectives of the workshop are not } \\
\text { very clear }\end{array}$ \\
\hline $\begin{array}{l}\text { Very useful information could be } \\
\text { collected }\end{array}$ & $\begin{array}{l}\text { Unnecessary interference by the } \\
\text { Faculty }\end{array}$ \\
\hline $\begin{array}{l}\text { Avoid unnecessary delays in } \\
\text { completing teaching practice }\end{array}$ & $\begin{array}{l}\text { Unable to find solutions to our } \\
\text { problems }\end{array}$ \\
\hline $\begin{array}{l}\text { Very challenging and meaningful } \\
\text { experience }\end{array}$ & $\begin{array}{l}\text { Our difficulties also should be } \\
\text { considered in an open mind }\end{array}$ \\
\hline
\end{tabular}




\section{What is the impact of redefined roles on the development of professional skills of student teachers?}

The Faculty staff strongly emphasized the need to re-orient the role of the Master Teachers from an assessment role to a supervisory role. At the training workshop, several activities were conducted to explain their new roles and responsibilities and every possible attempt was made to convince the importance of their guidance and advice for improving the professional skills of student teachers. However, the Faculty was very particular about separating the roles of School Mentors and Master Teachers in order to avoid conflicts which might affect adversely the professional development of student teachers. According to the responses of student teachers and University academics, the Faculty has failed in achieving this objective fully due to the inability of some Master Teachers to connect it to a vision of good teaching and professional practice. Their personal attributes also might have been an impediment for introducing the new procedures to the student teachers. It was further noted that irrespective of the instructions given by the Faculty, some of the Master Teachers were reluctant to change their practices. Students also complained about the different practices adopted by different Maser Teachers

In a distance education system, University academics have fewer opportunities to interact with their students and maintain close links with them. In line with the PGDE Programme, the Faculty identified a long felt need for conducting intensive training programmes and closely monitoring and supervising the activities of Master Teachers and student teachers. Therefore, the arrangements have been made to allocate Master Teachers and student teachers to internal academics and provide the guidance needed. The monitoring workshop was a novel experience for them and the continuous discussions and experience sharing among themselves helped them to use critical reflections and assess their own practices. The most encouraging aspect was that everybody was very keen on contributing to the quality improvement of the largest and most demanding programme of the Faculty. During this process, those who joined very recently have also developed their self confidence and improved necessary skills to undertake more challenging roles. 
G. D. Lekamge

\section{Actions to be taken by the Faculty in the future}

Having analysed the information collected using different sources, the actions to be taken by the Faculty to improve the existing conditions further were identified.

All the categories agreed that the appointment of School Mentors was an appropriate and timely decision taken by the Faculty. School Mentors themselves suggested (61\%) that the quality of their roles can be improved further by strengthening the training programmes conducted for both School Mentors and student teachers. Student teachers urged the need for identifying experienced and qualified teachers who do not have administrative responsibilities in the school as their mentors. There was a need to develop a work plan by both School Mentors and student teachers in relation to their school contexts and work accordingly to achieve the targets set for their professional development. There is a need to develop an incentive mechanism for School Mentors to compensate the invaluable contribution they make towards the professional development of student teachers. Some (46\%) wanted an awareness raising programme for school principals to explain their responsibilities towards the development of professional skills of student teachers. The benefits accrued to the schools by improving the capacities of their teachers should be understood. The schools should also develop training programmes for these teachers and give them the fullest support for the satisfactory completion of the Teaching Practice component. Having highlighted the critical connection between student teacher success and factors in school culture and organization, Huling-Austin stressed that "if the schools operate in ways that are unresponsive to the needs of the students, it is unreasonable to expect from novice teachers to learn to operate effectively in them" (1992, P 178-179) .

Internal staff members felt that the procedures implemented by the Faculty also need to be further modified and strengthened. Necessary steps should be taken by the Faculty to overcome the delays in making payments to all the categories involved in Teaching Practice.

According to student teachers more information is needed about the procedures to be adopted for completion of projects and writing reflective journals. It would be most beneficial if the schools can support student teachers by allocating some percentage of quality inputs to their projects. 
Continuous training should be provided for Master Teachers and those who do not adhere to the Faculty procedures should be removed from their respective roles. If possible, a collaborative approach should be adopted by both Master Teachers and School Mentors to understand the strengths and weaknesses of student teachers and to provide them the support and guidance needed.

Finally this whole procedure should be linked to a very broad perspective. As suggested by Felman-Nemser "If mentoring is to function as a strategy of reform, it must be linked to a vision of good teaching, guided by an understanding of teacher learning and supported by a professional culture that favors collaboration and inquiry" (1996, P 1) .

\section{Conclusions}

This study revealed that a well-planned mentoring system can facilitate the development of professional skills of student teachers. Through mutual understanding and a congruent relationship the selfconfidence, self-motivation, self regulation and reflection of student teachers could be developed. Such a programme could change the school culture by inculcating positive attitudes in those concerned and developing a supportive infrastructure to facilitate the development of professional skills of student teachers. It would contribute towards developing instructional leadership and management capabilities and monitoring and supervisory skills of School Mentors and improve their career advancement purposes. The exemplary qualities demonstrated by the University academics, School Mentors and Master Teachers would provide excellent models for both the novice and the experienced teachers. The procedural and contextual problems should be solved and professionalization of teachers should be inculcated. This whole process would ultimately improve the quality of teachers and the quality of teaching thereby improving the quality of learning and the quality of the final products of the education system. 


\section{References}

Donnelly, P ( 2010 ) Case Study on Mentoring in Initial Teacher Education Scotland, www.docstoc.com

Felman-Nemser, S (1996) Teacher Mentoring A Critical Review. ERIC Digest, http//www.ericdigests.org/1997-1/mentoring.html

Fisher, D and Andel, L. V ( 2002) Mentoring in Teacher Education- towards innovative school development, Paper presented at the 27th Annual Conference of ATTE, Warsaw, Poland

Huling - Austin, L (1992) A Synthesis of Research on Teacher Induction Programs and Practices, paper presented at the Annual Meeting of the American Education Research Association, New Orleans

Kennedy M.M. (1999) The Role of Pre-service Teacher Education in L. DarlingHammond \& G. Sykes (Eds) Teaching as a Learning Profession, Handbook of Policy and Practice (pp 54-85) San Fransisco: Jossey -Bass

Maynard, T \& Furlong, J (1993) Learning to teach and models of Mentoring in Mcintyre, D Hagger, H. \& Wilkin, M (Eds) Mentoring, perspectives on School - Based Teacher Education, London, Kogan page

Mutchler, S.E. (2010) Lessons from Research on Teacher Mentoring; Review of Literature, http//www.sedi.org/pubs/policy23/2.html

Stuart , C\& Thurlow, D. (2000) Making in their own: Pre-service Teacher Education experiences, beliefs, and classroom practices, Journal of Teacher Educaton , 51 (2) , 113-121

Report on Mentoring in Teacher Education, (2002) http// www.hmie.gov.uk/documents/ publication/ mite.html 